\title{
Metastatic Progression of Osteosarcomas: A Review of Current Knowledge of Environmental versus Oncogenic Drivers
}

\author{
Guillaume Anthony Odri ${ }^{1,2, * \mathbb{C}}$, Joëlle Tchicaya-Bouanga ${ }^{1}$, Diane Ji Yun Yoon ${ }^{1,2}$ and Dominique Modrowski ${ }^{1}$ \\ 1 INSERM UMR 1132, Biologie de l'os et du Cartilage (BIOSCAR), Lariboisière Hospital, UFR de Médecine, \\ Faculté de Santé, University of Paris, 75010 Paris, France; joelle.tchicaya-bouanga@inserm.fr (J.T.-B.); \\ dianejiyun.yoon@aphp.fr (D.J.Y.Y.); dominique.modrowski@inserm.fr (D.M.) \\ 2 Service de Chirurgie Orthopédique et Traumatologique, DMU Locomotion, Lariboisière Hospital, \\ 75010 Paris, France \\ * Correspondence: guillaume.odri@aphp.fr
}

Citation: Odri, G.A.;

Tchicaya-Bouanga, J.; Yoon, D.J.Y.; Modrowski, D. Metastatic Progression of Osteosarcomas: A Review of Current Knowledge of Environmental versus Oncogenic Drivers. Cancers 2022, 14, 360 . https://doi.org/10.3390/ cancers 14020360

Academic Editors: Françoise Rédini and Franck Verrecchia

Received: 3 December 2021

Accepted: 10 January 2022

Published: 12 January 2022

Publisher's Note: MDPI stays neutral with regard to jurisdictional claims in published maps and institutional affiliations.

Copyright: (C) 2022 by the authors. Licensee MDPI, Basel, Switzerland. This article is an open access article distributed under the terms and conditions of the Creative Commons Attribution (CC BY) license (https:// creativecommons.org/licenses/by/ $4.0 /)$.
Simple Summary: Osteosarcomas are heterogeneous bone tumors with complex genetic and chromosomic alterations. The numerous patients with metastatic osteosarcoma have a very poor prognosis, and only those who can have full surgical resection of the primary tumor and of all the macro metastasis can survive. Despite the recent improvements in prediction and early detection of metastasis, big efforts are still required to understand the specific mechanisms of osteosarcoma metastatic progression, in order to reveal novel therapeutic targets.

\begin{abstract}
Metastases of osteosarcomas are heterogeneous. They may grow simultaneously with the primary tumor, during treatment or shortly after, or a long time after the end of the treatment. They occur mainly in lungs but also in bone and various soft tissues. They can have the same histology as the primary tumor or show a shift towards a different differentiation path. However, the metastatic capacities of osteosarcoma cells can be predicted by gene and microRNA signatures. Despite the identification of numerous metastasis-promoting/predicting factors, there is no efficient therapeutic strategy to reduce the number of patients developing a metastatic disease or to cure these metastatic patients, except surgery. Indeed, these patients are generally resistant to the classical chemo- and to immuno-therapy. Hence, the knowledge of specific mechanisms should be extended to reveal novel therapeutic approaches. Recent studies that used DNA and RNA sequencing technologies highlighted complex relations between primary and secondary tumors. The reported results also supported a hierarchical organization of the tumor cell clones, suggesting that cancer stem cells are involved. Because of their chemoresistance, their plasticity, and their ability to modulate the immune environment, the osteosarcoma stem cells could be important players in the metastatic process.
\end{abstract}

Keywords: osteosarcoma; metastasis; surgery; chemo-resistance; cancer stem cells

\section{Introduction}

The presence of macroscopic metastasis is the strongest predictor of survival of patients with osteosarcoma [1,2]. The mean 5-year overall survival rate for patients with metastases remains very low, below 30\% [2-4]. The metastatic spread is heterogeneous. Indeed, metastases can be detected at the initial diagnosis or appear at the short or long term after treatment. Some patients develop metastases during treatment, which indicates refractory osteosarcoma, and these have the worst prognosis. Although the most common sites are lungs and bones [5], metastasis can appear in many other tissues. The secondary lesions can be unique or multiple, and patients with several metastases have a worse prognosis [6]. Hence, we need a better understanding of the origin of the heterogeneity and the specific mechanisms that could be targeted to stop or prevent these secondary diseases. 
Here, we review the different types of relapses/metastases that have been clinically characterized in osteosarcoma and recent knowledge of mechanisms underlying the occurrence of osteosarcoma-associated metastases.

\section{Clinical Presentation of Metastases}

\subsection{Synchronous Metastases}

Metastases that are detected at diagnosis are called synchronous because they develop in parallel with the primary tumor (Figure 1). In high-income countries, synchronous metastases are detected in $10 \%$ to $30 \%$ of patients with osteosarcoma, a proportion that has not changed in the past 50 years [2,3,5-7]. However, in low- and middle-income countries, with delayed diagnosis, up to $40 \%$ of patients have metastatic disease at presentation [8]. The diagnostic delay of osteosarcoma has improved in past decades in high-income countries, so the rate of patients with metastasis at diagnosis should have decreased, but, at the same time, modern imaging techniques lead to earlier detection of these metastases, possibly counterbalancing the number of patients with detected synchronous metastases [9]. We can extrapolate that we may still not be able to detect every macro and micro-metastatic disease foci, and early detection of disseminated cells might be a crucial point to better manage the metastatic disease. This is suggested by histological analyses of amputated limbs or autopsies of patients with osteosarcoma, revealing a far greater number of metastases than could be detected by imaging techniques. For example, histological analyses of resected lungs reveal more metastases than did the pre-operative CT scan [10]. Therefore, the exact proportion of patients with metastases at diagnosis could be much higher. This hypothesis is also supported by the very low proportion (only 20\%) of patients who survived after being treated with surgery alone, before the introduction of chemotherapy [11]. These $20 \%$ long-term surviving patients could be truly non-metastatic at diagnosis, all the others having macro- or micro-metastases. Thus, despite improvements in imaging techniques and biopsies, we still need new tools to detect or predict metastatic disease and to discriminate metastatic and non-metastatic osteosarcoma. Identified risk factors associated with the occurrence of lung metastasis at diagnosis are delayed diagnosis, increased tumor grade and size $(>5 \mathrm{~cm})$, or an axial localization and presence of bone or brain metastases $[7,9,12]$.

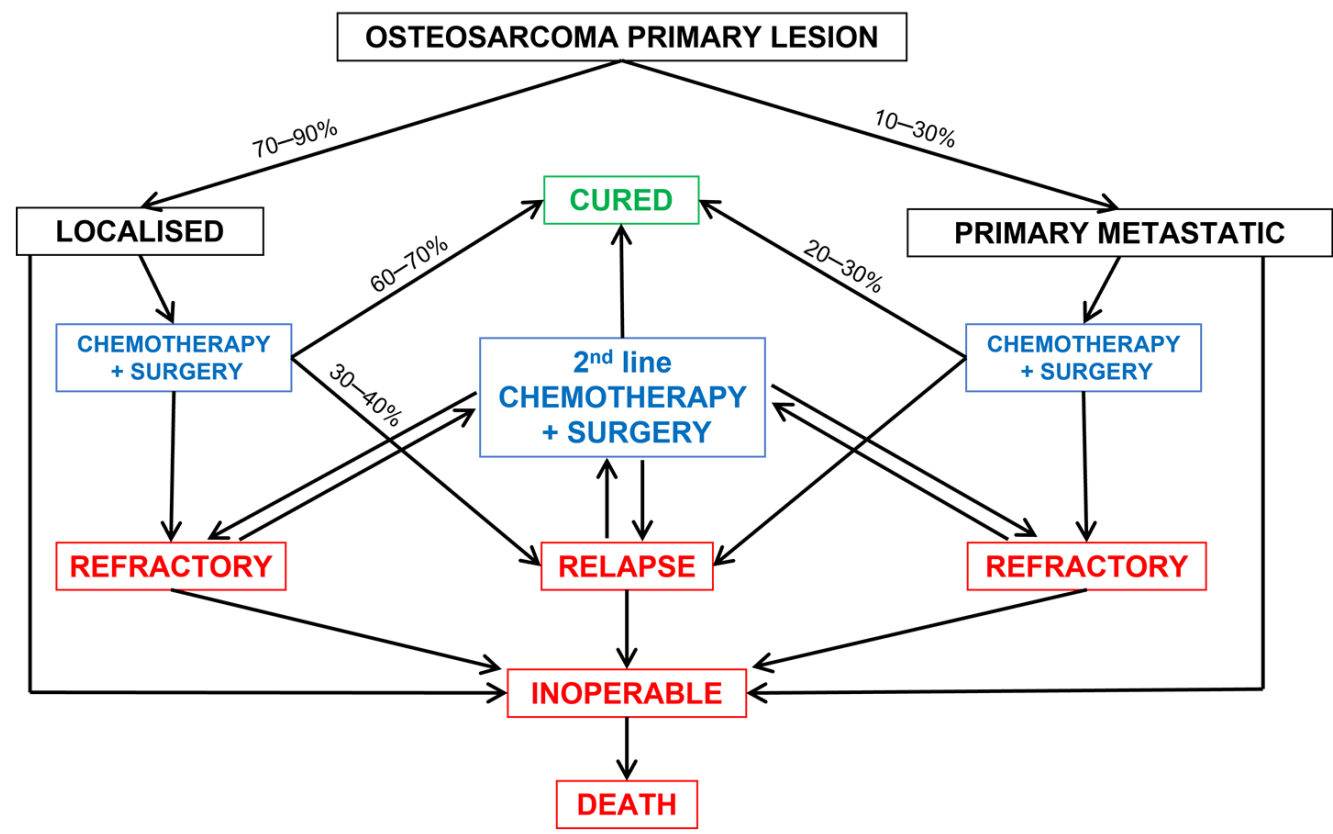

Figure 1. Metastatic evolution in osteosarcoma. The outcome depends on the occurrence of metastasis before diagnosis and/or relapse after treatment, the response to chemotherapy, and the possibility for full surgical resection. The text in black is for initial presentation, the text in blue is for therapeutic option, the text in red is for unfavorable evolution and the text in green is for favorable evolution. 
Synchronous metastases are mostly detected in the lungs (80\% of the metastases) [13]. Synchronous bone metastases are found in $10 \%$ to $30 \%$ of the patients, and in $30 \%$ to $45 \%$ of autopsy cases [13-15]. Bone metastases are considered secondary events of lung lesions because most patients with bone metastases also have lung lesions. However, bone metastases can develop without or before any other non-skeletal metastases. In 1975, Enneking et al., in a systematic histological analysis of the entire limb bones after amputation for osteosarcoma, found a metastasis in the same bone in $25 \%$ of the cases. This type of lesion is called skip metastasis [16], defined as a second foci of tumor cells within the same bone as the primary lesion but separated from the primary foci by normal marrow tissue. Occasionally, skip metastasis may arise at an opposing side of a joint and is then called a trans-articular skip metastasis. Skip metastasis can be single or multiple, distal, or proximal to the primary tumor. They are found in $1.4 \%$ to $10 \%$ of patients and are best seen on MRI [17-22]. According to the American Joint Committee on Cancer staging system for primary malignant bone tumors, patients with a discontinuous tumor in the primary bone site with no regional lymph node or other distant metastasis are considered at stage 3 , whereas the presence of lung metastasis is considered stage $4 \mathrm{a}$, and the presence of distant bone metastases or other organ metastases is considered stage $4 \mathrm{~b}$.

When osteosarcoma occurs on several bones at diagnosis without lung metastases, it is called multifocal osteosarcomas (MFOSs), or multicentric osteosarcomas. This type of osteosarcoma accounts for $1 \%$ to $3 \%$ of cases [23]. Whether these MFOSs are primary osteosarcomas with bone metastases or different and independent primary osteosarcomas arising in different bones is debatable. Most of the synchronous MFOS cases have a large tumor associated with smaller tumors, which may favor a metastatic spread hypothesis, but synchronous MFOS with all lesions being the same size have also been described [24]. Histological analysis of simultaneously resected tumors from two bone sites revealed the same response rate to chemotherapy in the two lesions, which supports the hypothesis of bone-to-bone metastases from a primary tumor [25].

Patients with synchronous metastases have heterogeneous outcomes, depending on the number and distribution of the metastases. For example, the mean 5-year event-free survival with unilateral lung metastases is up to $75 \%$ but decreases to $0 \%$ for patients with synchronous MFOS [25]. Independent prognostic factors for patients with synchronous lung metastases are the possibility of complete metastasectomy and the response to chemotherapy [26]. Recent studies reported that $45 \%$ of patients with skip metastasis survived after 5 years, the prognosis being better with skip metastases in the same bone versus trans-articular skip metastases [3,18,19,22].

\subsection{Metachronous Metastases}

Metastases that appear after the end of treatment are considered relapses or recurrences (Figure 1). These relapses are called early when they appear during the 24 months after the end of treatment, late when they appear after 5 years, and very late after 10 years [27-29]. Chemotherapy has strongly reduced the early metastatic/relapse events in patients and delayed the appearance of metachronous metastases. However, more cases of late and very late recurrences up to more than 20 years have been reported. These relapses are mainly in lungs. Prior to chemotherapy, $80 \%$ to $90 \%$ of patients showed relapse, and, since the introduction of chemotherapy, this rate has decreased to $30 \%$ to $50 \%[6,7,14,30-33]$. Furthermore, the mean time to the first relapse was about 6 to 9 months after surgery alone and is now greater than 18 months $[1,13,33,34]$. Chemotherapy has also changed the pattern of relapse. Most patients (80-90\%) showed lung metastases, and other sites were clinically involved in less than $20 \%$ [13]. Now, $60 \%$ to $80 \%$ of patients show relapse in lungs and $20 \%$ to $40 \%$ in other sites. These sites can be bone, bowels, heart, brain, eyelid, epidural, muscle, pancreas, adrenal gland, eye, skin, stomach, or breast $[14,30,32,34]$. Of note, lymph node metastases seem to be rare in osteosarcoma and can be found clinically in $4 \%$ of patients but are detected in up to $28 \%$ at autopsy [13]. Chemotherapy has also 
changed the number of metastases at relapse, from $72 \%$ of patients with bilateral lung metastases to less than $30 \%[13,14,30,32,34]$.

In contrast, chemotherapy did not significantly change the survival of patients with metachronous metastases. In recent studies, the median post-metastasis survival is about 22 months, and the 5 -year overall survival is $28 \%$ to $38 \%$ [2,5,35].

The risk factors for lung metastasis after treatment are male sex, tumor size $\geq 8 \mathrm{~cm}$, histological grade G2, Enneking stage II, anatomic location to the distal femur, pathological subtype (conventional osteosarcoma), and high level of alkaline phosphatase at diagnosis [36]. The prognostic factors associated with better survival are the timing of metastasis [35], younger age ( $<60$ years old), and surgical treatment of the primitive tumor [7]. The prognostic factors associated with short survival are primitive tumor size ( $>3$ or $8 \mathrm{~cm}$ ), histological subtype (chondroblastic versus osteoblastic), histological grade G2, Enneking stage II, early metastasis, local recurrence before metastasis, extrapulmonary metastasis, multiple pulmonary metastases, poor response to primary chemotherapy, lack of curative treatment after metastasis, including metastasectomy, increased level of alkaline phosphatase at diagnosis and lactate dehydrogenase after metastasis [5,36-38].

Osteosarcomas with isolated bone recurrence in the absence of any lung metastasis were previously classified as metachronous MFOSs. They represent $1 \%$ of osteosarcomas [39]. As with synchronous MFOSs, these secondary lesions could be metastatic or second independent osteosarcomas. However, it is difficult not to see a metastatic relation between the primary lesion and the secondary bone lesion, even in the absence of lung metastases, because metachronous metastases in organs other than lungs and bone (such as brain or pancreas) can be detected in the absence of lung metastases, thus showing other routes of metastatic dissemination. However, for very late metachronous MFOSs in patients with predisposing syndromes, such as p53 or Rb mutations, a second independent osteosarcoma cannot be ruled out. Patients with metachronous MFOSs have a better survival rate than those with synchronous MFOSs [23].

Local recurrence is considered when the tumor relapses at the site of the primary surgery. It accounts for $5 \%$ to $10 \%$ of relapses. Debate has been ongoing as to whether or not the local recurrences after limb salvage surgery could relate to the persistence of skip metastases in the bone that harbored the primary tumor because no local recurrence was reported after radical excision of the entire bone [17,40]. In contrast, different studies indicate a correlation between local recurrence and surgical margins, thus suggesting a possible residual disease of the primary tumor [41].

In some patients, metastases appear during neoadjuvant chemotherapy. These osteosarcomas are called refractory (Figure 1), and they are resistant to chemotherapy and have a worse prognosis of only $8 \%$ overall survival at 5 years.

\subsection{Treatment of Metastatic Osteosarcoma}

The best treatment regimen for patients with synchronous metastases is still not clear but should include chemotherapy protocols associated with primary lesion resection and metastasis resection [42]. For lung metastases, an aggressive surgical attitude including removal of metastases at several sites has been found efficient in increasing survival $[4,26,43]$. For patients with synchronous skip metastases, surgical resection of the primary tumor, including the skip metastases, is required [3]. Patients with synchronous metastasis in other organs or inoperable multiple metastasis often exhibit multiorgan involvement and a rapid progressive disease with a very poor short-term prognosis [3].

There is no standard treatment for patients with relapse. Patients with lung metastases should undergo metastasectomy when possible, and repeated thoracotomy can be required [42]. Complete remission is achieved only in patients with full surgical resection of all the metastasis. Second-line chemotherapy associated with surgery can increase survival as compared with surgery alone, but its exact modality is still debated $[26,44,45]$. In a recent review, Gazouli et al. evaluated 56 phase I and II trials for new treatment strategies in recurrent/metastatic osteosarcoma over the last 2 decades; strategies included 
cytotoxic chemotherapy, targeted agents, such as tyrosine kinase, and mammalian target of rapamycin inhibitors, immunotherapy, and combination approaches [44]. Most of these studies failed to show any benefit of these new drugs. High-dose chemotherapy followed by peripheral blood stem cell reinfusion showed some promising results but must be confirmed in prospective and randomized clinical trials [46]. Immunotherapy with anti-CTLA4 (pilimumab) or anti-PD1 (pembrolizumab and nivolumab) monoclonal antibodies conferred only a short stabilization of disease for a very few patients [47-49]. Human epidermal growth factor receptor (HER2)-directed CART cells in 16 patients with HER2-expressing osteosarcomas stabilized the disease for 12 weeks in three patients, and one patient showed $90 \%$ tumor necrosis on histological analysis after surgical excision [50].

In conclusion, the presence of metastasis during osteosarcoma development is a predictor of poor prognosis. Metastatic diseases are heterogeneous, and the timing, the number, the size, and, probably, other factors also affect patients' outcomes. Only patients with full surgical resection of all macro metastasis can survive. However, the presence of micro metastatic foci may be frequent and very early events in osteosarcoma progression. Such cases cannot be treated by surgery and may persist after treatment because they contain refractory tumor cells that are resistant to chemotherapy. Many new therapeutic options, including targeted therapy, immunotherapy, and intensive chemotherapy with peripheral blood stem cell reinfusion, are under investigation, but none have yet shown a major change in overall survival.

\section{Mechanisms of Metastasis Formation}

\subsection{Metastasis Heterogeneity}

An important question is why consensus sets of targetable genes or miRNAs are still missing and why we cannot develop a therapeutic strategy to reduce the number of patients with a metastatic disease, despite the identification of numerous metastasispromoting/predicting factors. The heterogenicity of the metastatic tissues could be part of the answer. Histological comparisons of primary osteosarcomas and the associated lung metastases first revealed a large variety in the dissemination process [51]. Indeed, unilateral, bilateral solitary and multiple lung lesions were described. In a group of 20 bone sarcomas that were compared to lung lesions, $60 \%$ had identical osteoblastic or chondroblastic histology, and 40\% had a different histology [51]. Recently, genomic and transcriptomic analyses further documented the complex relations between primary bone tumor and metastases [52-54]. Wang et al. showed metastatic lesions with increased mutational burden and genome instability as compared with matched primary tumors [52]. Moreover, metastatic cell clones still have common genomic alterations with the primary tumors or, in contrast, strongly different genomic landscapes. These genetic divergences may result from different dissemination timing, with part of the metastases deriving from the mature tumor and part evolving in parallel with the bone tumor [52,53]. It was reported that metastases may be end-products of mature solid tumors or result from dissemination occurring early or continuously during tumor development $[55,56]$. It will be interesting to determine whether the notion of linear versus parallel evolution of the genetic pattern in metastases could overlap those of metachronous/synchronous metastasis because of the increased survival delay between bone tumor resection and metastasis initial occurrence in patients with linear evolution patterns compared to patients with parallel evolution [52]. Further genetic and transcriptomic analyses are also required to compare the different types of metastases (synchro versus metachronous and lung versus bone versus metastases in other sites).

\subsection{Regulation of the Metastatic Capacity of Primary Tumor Cells}

The formation of metastases strongly depends on the ability of tumor cells to leave the primary site. In line with this, the frequency of circulating osteosarcoma cells was found higher in patients with metastases than in those with a localized tumor, and the presence of circulating cells with mesenchymal characteristics after treatment can predict 
relapse and metastases occurrence [57,58]. A large number of studies focused on factors and signaling pathways that could affect the metastatic capacity of primary tumor cells. The studies analyzed cell migration/invasion using cell lines and metastasis formation in mouse models and compared transcriptomes of metastatic and non-metastatic tumors and primary tumors with metastatic tissues [54,59]. Genes that could be metastasis drivers have been extensively studied, but, more recently, epigenetic regulations by long noncoding RNAs, microRNAs (miRNAs), and circular RNAs have gained interest [60-66]. These non-coding RNAs also serve as prognostic markers [67-69]. Identifying their targets highlighted that cellular processes, such as metabolism, autophagy, and adaptation to hypoxia, are altered with the metastatic potential of tumor cells [70-72]. The prognosis signatures also documented modifications of the tumor environment, thus indicating that the development of metastases is associated with altered cytokine production and immune cell recruitment [71,73].

\subsection{Epithelial-Mesenchymal Transition (EMT)}

Despite being contra-intuitive given their mesenchymal origin, the EMT seems to be a key process for sarcoma cell reprogramming towards increased metastatic potential [74,75]. Recently, a prognostic signature was found to include the gene fragile histidine triad diadenosine triphosphatase (FHIT), which is downregulated in osteosarcoma tissues versus normal osteoblasts. Rescuing its expression in osteosarcoma cells resulted in downregulation of $\mathrm{N}$ cadherin and vimentin and upregulation of E-cadherin, which indicates that FHIT controls the switch between mesenchymal and epithelial markers [67]. These results demonstrate the relation between the risk of metastatic progression and EMT in patients. In addition, the presence of the mesenchymal marker $\mathrm{N}$-cadherin in osteosarcoma-derived vesicles predicted metastasis progression [76]. Micro-vesicles display markers of original cells, which further links the EMT process to the metastatic potential of tumor cells. Various long non-coding RNAs and miRNAs have been shown to regulate the EMT and, thus, affect the metastatic behavior of tumor cells [74]. Especially, these RNAs modulate the expression of transcription factors, such as zinc finger E-box binding homeobox 1 (ZEB1) [77-79], Twist1 [80], or signal transducer and activator of transcription 3 (STAT3) [81] and signaling pathways, including the Wnt/ $\beta$-catenin and NOTCH pathways $[82,83]$.

The effectors of the Hippo pathway, YAP and TAZ, are key regulators of the plasticity of osteosarcoma cells [84]. This signaling pathway integrates mechanical and nutritional cues to drive the cell adaptation to ECM physical properties, cell junction modifications, oxygen level, or mechanical stresses (Figure 2) [85-88]. The Hippo cascade is interconnected to multiple pathways, depending on the activation of receptor tyrosine kinases, transforming growth factor $\beta, \mathrm{NOTCH}, \mathrm{Wnt}, \mathrm{G}$-protein-coupled receptors, or integrins, which together modulate YAP/TAZ nuclear translocation and transcriptional activities of transcriptional enhanced associate domain (TEAD) or Smad [89-91]. YAP/TAZ control the EMT process directly by modulating EMT genes or indirectly by modulating signaling pathways (Figure 2) [92]. In contrast, YAP and TAZ can interact directly with the key transcription factors of the EMT, snail family transcriptional repressors (SNAIL and SLUG) and ZEB1, in mesenchymal stem cells [93]. Hence, these transcription complexes could promote the acquisition of mesenchymal/pro-metastatic capacities in undifferentiated tumor cells.

\subsection{Role of the Microenvironment}

\subsubsection{Extracellular Matrix}

Aside from intrinsic properties, cell evasion from tumors also depends on the tumor microenvironment. Tumors are complex associations of different types of cells, including fibroblasts and endothelial and immune cells, which communicate via metabolites, cytokines, growth factors, and micro vesicles. Tumor cohesion is ensured by the extracellular matrix. Matrix proteins, such as collagens, fibronectin, and laminins, have important roles in support of cancer progression and metastases by affecting cell adhesion and migra- 
tion and modulating integrin signaling and matrix metalloproteinase expression [94-96]. Zandueta et al. identified the matrix-Gla protein (MGP) in transcriptomic profiles of osteosarcomas. The authors showed that MGP affects endothelial adhesion, trans-endothelial migration in vitro, and tumor cell extravasation ability in vivo. Patients with metastasis had high levels of tumor and circulating MGP, and suppression of the protein resulted in reduced metastasis development in mice [97]. Hence, altering interactions between osteosarcoma cells and specific matrix proteins may offer therapeutic options to prevent the first steps of the metastasis process.
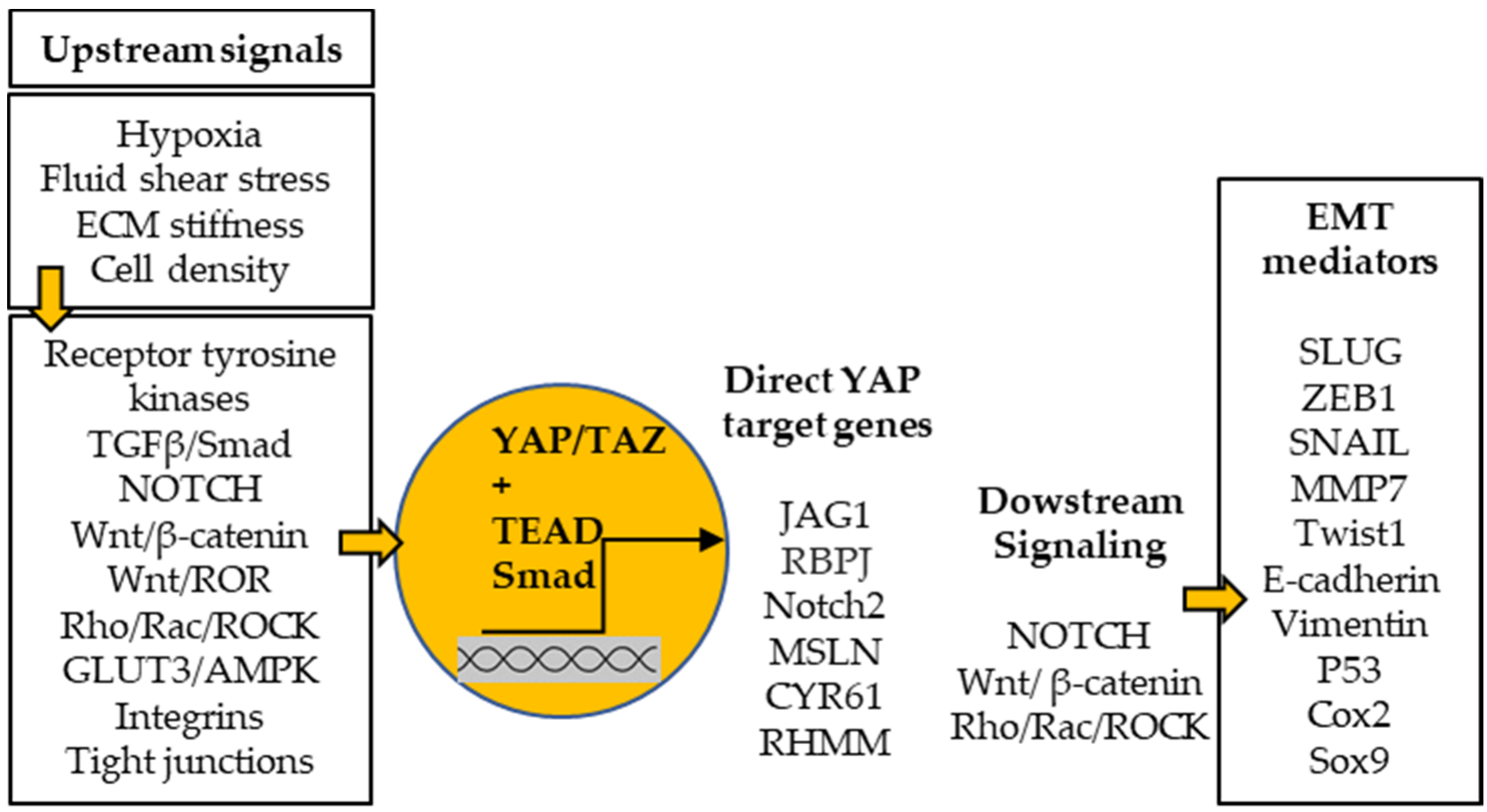

Figure 2. Effectors of the Hippo pathway, YAP/TAZ, are at the core of the epithelial-mesenchymal transition (EMT) regulation. Their nuclear translocation and transcriptional activities depend on microenvironment cues and the multiple signaling pathways that integrate these signals to induce cell adaptation. YAP/TAZ, in turn, modulate the expression of genes and activity of signaling pathways involved in the EMT.

\subsubsection{Tumor Associated Macrophages}

The role of tumor associated macrophages (TAMs) in the promotion of cancer cell invasion and metastasis capacities has been documented in diverse cancers [98]. In the same way, evidence of the contribution of these cells to the metastatic progression of osteosarcomas was reported in cell and mouse models. These studies revealed that TAMs communicate with tumor cells to activate a cyclooxygenase 2-STAT3 axis and promote the EMT [99]. Maloney et al. reported that an inhibitor of epidermal growth factor receptor acted on TAMs and reduced invasion capacity and the metastatic burden in mice [100]. Moreover, muramyl tripeptide phosphatidylethanolamine, which activates monocytes and macrophages, had encouraging effects in patients with recurrent osteosarcomas [101,102]. However, the numerous studies of TAMs in patients led to diverse conclusions about the identity of these immune cells and the association with prognosis. Mainly, TAM infiltration was associated with better prognosis $[103,104]$. Some authors found that higher ratios of macrophage 1 to 2 (M1/M2) better predicted overall and disease-free survival [105]. Depending on the methods, M0, M1, and/or M2 macrophages were found within tumors $[103,106,107]$. Zhou et al. also identified alveolar macrophages with a proinflammatory phenotype in lung metastatic tissues [106]. Whether macrophage-like cells could be targets to prevent or treat osteosarcoma metastasis is a major issue for improving or implementing novel immunotherapies. 


\subsection{Regulation of the Metastatic Niche}

The notion of "metastatic inefficiency" was established in mouse models because of the observation that most of the tumor cells injected in the circulation died some days after metastatic site colonization [108]. Hence, metastasis formation seems to be a selective process. The primary tumors do not just provide cells with intrinsic properties to survive outside the tumors and colonize other sites; they also produce growth factors, cytokines, and miRNAs that can be transported in extracellular vesicles (EVs) to modify local and distant sites and influence metastatic niches, thereby fostering the development of disseminated tumors [109]. Macklin and colleagues isolated EVs from highly metastatic osteosarcoma cell clones and showed their preferential translocation to lungs [110]. The fusion protein Rab22a-NeoF1 and its partner PYK2 were recently found produced in EVs by subpopulations of osteosarcoma cells; they can "pre-educate" the lungs of tumor-free mice to induce a higher expression of chemokines and the recruitment of macrophages to enhance metastatic development [111]. Mechanistically, the growth factor transforming growth factor $\beta$ transported in EVs induced differentiation/activation of lung fibroblasts with increased expression of fibronectin [112].

However, in other models of human tumor cell xenografts in mice, osteosarcoma cell derived EVs induced macrophage accumulation in lungs but had no effect on metastasis development [113]. This finding suggests that tumor derived EVs may not be the only required messengers. It also points out that metastasis development may require a "soil" with intrinsic permissive characteristics. Clearly, tumor-independent events affect metastatic development because metastasis outgrowth can occur in patients long after primary tumor resection. These events may be related to vascularization, metabolism, and immunity.

Thus, metastasis outgrowth is not only driven by specific gene alterations in tumor cells but also depends on the permissiveness of the environment $[114,115]$. The tumorindependent conditions that promote metastatic disease in osteosarcoma is a large field to be explored.

\subsection{Metastasis Cell Founders}

Two main models of tumorigenesis have evolved in parallel. The stochastic one predicts that tumor cell clones undergo Darwinian selective pressure to survive and grow. The other model includes particular tumor cells with stemness features and implies a hierarchical organization. These mechanisms are not exclusive and can be equally involved in the formation of primary osteosarcomas. Despite the extensive documentation of cancer stem-like cells in osteosarcomas, the possible contribution of these cells to the metastatic process is still unclear.

Clonal progression of osteosarcoma metastases was first supported by tracing experiments that showed a polyclonal seeding in lungs from bone tumor [116]. Of note, these experiments were conducted in immunodeficient mice and did not consider the possible selection of tumor clones by the immune system. However, phylogenetic analyses confirmed the polyclonal features of metastatic lesions in patients [52,53]. Single-cell RNA sequencing also identified diverse osteosarcoma cell populations with specialized characteristics (i.e., high proliferation, angiogenesis, interferon- $\alpha$ (IFN- $\alpha)$ and IFN- $\gamma$ production, MYC expression and oxidative phosphorylation, hypoxia signaling, or inflammatory responses) [106]. By analyzing differentiation gene signatures in cell clones of chondroblastic osteosarcomas, these authors revealed that malignant chondroblastic osteosarcoma cells could be transdifferentiated into malignant osteoblastic cells. Liu and colleagues further demonstrated the presence of particular osteoblastic clones within bone tumors that are at the starting position of differentiation paths [117]. This was the first evidence in patients that osteosarcoma cell clones may not develop independently but are linked by hierarchical relationships and derive or "differentiate" from each other as shown in other types of tumors [118,119]. Together, these data further support the concept of cancer stem/precursor cells (CSCs) that contribute to osteosarcoma tumorigenesis. Different teams have described osteosarcoma cells that grow in spheres, express embryonic stem cell markers, and have high tumorigenic 
capacity [120,121]. We identified calpain-6 as a marker of sarcoma SCs [122] and showed that calpain-6-expressing cells are at the top of a cell hierarchy. These cells were able to rest as a slowly growing/dormant disease in lungs, months after orthotopic implantation of a few osteosarcoma cells in mice [122]. Hence, sarcoma SCs could specifically contribute to the metastatic process, but the mechanisms remain to be further elucidated.

In patients, CSCs could be selected after chemotherapy and be responsible for the residual disease owing to their chemoresistance capacity [123-126]. The most characterized CSCs are carcinoma SCs. In comparing early and advanced lung metastases of breast carcinoma, cells of low-burden metastases expressed CSC markers, whereas cells of high-burden lesions had the same gene signature as the primary tumors [127]. This finding suggests that carcinoma SCs are involved during early steps of metastasis outgrowth and that metastases could evolve similar to the primary tumors. In support of this, the acquisition of a metastatic behavior is strongly correlated with the EMT program in CSCs [128-130]. However, metastasis development also depends on cell plasticity and the ability to produce committed epithelial progeny. Indeed, blocking tumor cells in the mesenchymal phenotype was sufficient to inhibit metastasis progression in different models of epithelial cancer [127,131]. In the same way, the EMT program seems closely associated with both stemness and metastasis capacities during osteosarcoma progression [132,133]. On the other hand, metastatic capacity is correlated with SC features. For example, the metastatic potential of osteosarcoma cells was found correlated with aldehyde dehydrogenase 1A1 activity, a well-known CSC marker [134]. Enhanced transglutaminase 2 expression in metastatic osteosarcomas contributes to the migratory and invasive properties of tumor cells but also to stem cell phenotype [135]. Zhang et al. found that osteosarcoma SCs can undergo myofibroblastic reprogramming that mimics a process of non-tumor myofibroblasts by inducing fibrosis in lungs, which, in turn, promotes metastasis growth [136]. Hence, osteosarcoma SCs have specific features, such as the EMT, high migration capacity, chemoresistance, and plasticity, so they are strong candidates to drive an efficient metastatic process.

One possible mechanism to explain the ability to re-initiate tumor development after treatment is that CSCs modulate immune environment and can induce local immunosuppression [137]. An ancient idea is that, because cancer cells differ from normal cells owing to genetic instability and a high rate of mutations, tumor growth should induce innate and adaptive immune responses. In support of this, cancer-specific antigens have been identified, and an immune surveillance was shown to keep metastasis cells quiescent [138]. However, CSCs can overcome this constraint by intrinsic mechanisms and by modeling a specific microenvironment. For example, similar to normal SCs, CSCs express low levels of class I major histocompatibility complex [139]. In contrast, CSCs express high levels of programmed death ligand 1, a checkpoint inhibitor that suppresses T-cell activation and promotes T regulatory cell differentiation $[140,141]$. Alternatively, a CSC-specific microenvironment called a niche was found to comprise matrix proteins, such as tenascins, which inhibit CD4+ and CD8+ T-cell activation and proliferation and production of IFN- $\gamma$ [142]. Finally, much evidence indicates that the dialogue between CSCs and the environment results in the production of a specific set of inflammatory mediators that, in turn, regulate the recruitment and differentiation of the immune cells [137]. In conclusion, CSCs are able to affect the immunity set point, that is, the balance determining pro- or anti-tumor immunity, and could thereby escape immune control.

\section{Conclusions and Perspectives}

Chemotherapy has improved the outcome of patients with a local bone tumor. However its impact on metastatic diseases is less clear. Chemotherapy has changed the timing, the pattern, and the number of metastases, but it did not significantly change the survival of patients. Only 20 to $30 \%$ of the patients with synchronous metastases and $30-40 \%$ of the patients with metachronous metastases can be cured, and, for this, full surgical resection of the metastases must be achieved. Targeted therapy, immunotherapy and intensive 
chemotherapy with peripheral blood stem cell reinfusion are under investigation and have not yet shown a major change in the overall survival [143-146].

Better understanding of the mechanisms of metastasis formation is, therefore, mandatory to find new therapeutic targets. In the recent years, innovative technologies have highlighted several key pathways that regulate the metastatic capacity of the primary tumor cells, such as epigenetic regulations by small and long non-coding RNAs and genomic alterations, the importance of the Hippo pathway in the EMT of osteosarcoma cells, the role of extracellular matrix and cells infiltrating the tumor in the promotion of cell mobility and metastatic capacity, and the host tissue modifications into a metastatic niche by extracellular vesicles from the primary tumor (Figure 3). Osteosarcoma stem cells specific features have been better characterized, and these are strong candidates to drive an efficient metastatic process through the modification of the immune environment.

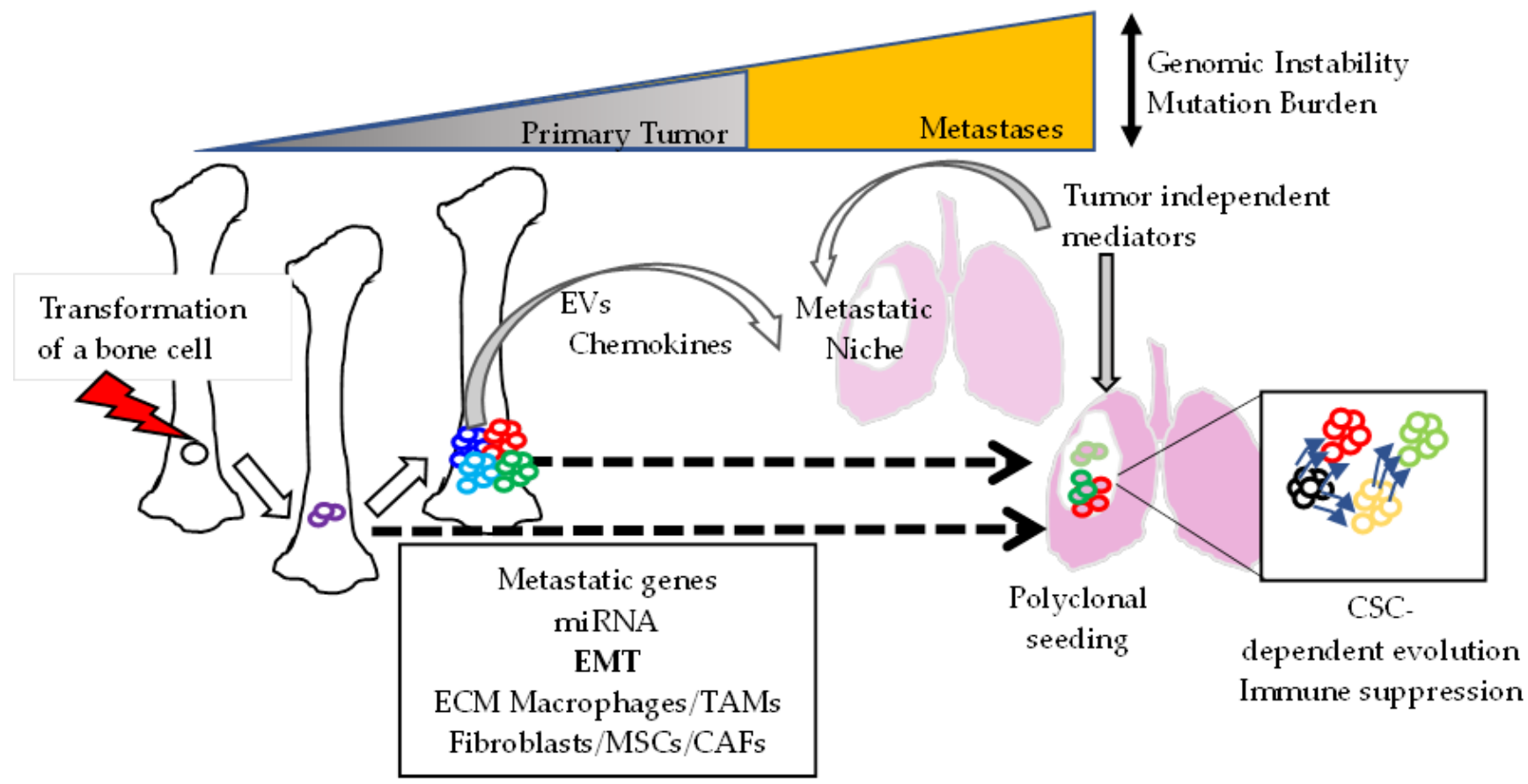

Figure 3. Schematic view of the formation of osteosarcoma-derived lung metastases accompanied by increased genomic alterations. The metastatic capacity of bone tumor cells depends on gene alterations (metastatic genes) and epigenetic regulation by microRNA (miRNA). Both can contribute to the epithelial-mesenchymal transition (EMT). The extracellular matrix (ECM) and tumor-associated fibroblasts (CAFs) and macrophages (TAMs) are responsible for microenvironment-mediated promotion of tumor progression. Cells can escape the primary site during early or late stages of tumor development (as indicated by the dotted arrows). The primary tumor produces factors that can travel in extracellular vesicles (EVs) to induce or activate metastatic niches. The metastatic niche could be regulated by tumor-independent factors that induce the host to be highly permissive for metastasis development. Polyclonal seeding can be associated with a hierarchical progression, with cancer stem cells (CSCs) as an initiating population of metastases. MSCs, mesenchymal stem cells.

Systematic tumor molecular profiling by DNA and RNA next generation sequencing on primary tumors and metastases biopsies, recognition of the immune molecular signatures, and identification of specific osteosarcoma stem cells molecular targets will hopefully allow the development of novel targeted therapies and may offer personalized treatments for improved clinical result in patients with metastatic disease. 


\begin{abstract}
Author Contributions: G.A.O. and D.M. contributed equally to this review. Conceptualization, G.A.O. and D.M.; writing-original draft preparation, G.A.O., D.M., J.T.-B. and D.J.Y.Y.; writing-review and editing, G.A.O., D.M., J.T.-B. and D.J.Y.Y.; supervision, D.M. All authors have read and agreed to the published version of the manuscript.
\end{abstract}

Funding: This research received no external funding.

Conflicts of Interest: The authors declare no conflict of interest.

\title{
References
}

1. Bielack, S.S.; Kempf-Bielack, B.; Delling, G.; Exner, G.U.; Flege, S.; Helmke, K.; Kotz, R.; Salzer-Kuntschik, M.; Werner, M.; Winkelmann, W.; et al. Prognostic factors in high-grade osteosarcoma of the extremities or trunk: An analysis of 1702 patients treated on Neoadjuvant Cooperative Osteosarcoma Study Group Protocols. J. Clin. Oncol. 2002, 20, 776-790. [CrossRef]

2. Smeland, S.; Bielack, S.S.; Whelan, J.; Bernstein, M.; Hogendoorn, P.; Krailo, M.D.; Gorlick, R.; Janeway, K.A.; Ingleby, F.C.; Anninga, J.; et al. Survival and prognosis with osteosarcoma: Outcomes in more than 2000 patients in the EURAMOS-1 (European and American Osteosarcoma Study) cohort. Eur. J. Cancer 2019, 109, 36-50. [CrossRef]

3. Kager, L.; Zoubek, A.; Pötschger, U.; Kastner, U.; Flege, S.; Kempf-Bielack, B.; Branscheid, D.; Kotz, R.; Salzer-Kuntschik, M.; Winkelmann, W.; et al. Primary metastatic osteosarcoma: Presentation and outcome of patients treated on neoadjuvant cooperative osteosarcoma study group protocols. J. Clin. Oncol. 2003, 21, 2011-2018. [CrossRef]

4. Bacci, G.; Rocca, M.; Salone, M.; Balladelli, A.; Ferrari, S.; Palmerini, E.; Forni, C.; Briccoli, A. High grade osteosarcoma of the extremities with lung metastases at presentation: Treatment with neoadjuvant chemotherapy and simultaneous resection of primary and metastatic lesions. J. Surg. Oncol. 2008, 98, 415-420. [CrossRef] [PubMed]

5. Kim, W.; Han, I.; Lee, J.S.; Cho, H.S.; Park, J.W.; Kim, H.S. Postmetastasis survival in high-grade extremity osteosarcoma: A retrospective analysis of prognostic factors in 126 patients. J. Surg. Oncol. 2018, 117, 1223-1231. [CrossRef] [PubMed]

6. Meyers, P.A.; Heller, G.; Healey, J.H.; Huvos, A.; Applewhite, A.; Sun, M.; LaQuaglia, M. Osteogenic sarcoma with clinically detectable metastasis at initial presentation. J. Clin. Oncol. 1993, 11, 449-453. [CrossRef] [PubMed]

7. Zhang, C.; Guo, X.; Xu, Y.; Han, X.; Cai, J.; Wang, X.; Wang, G. Lung metastases at the initial diagnosis of high-grade osteosarcoma: Prevalence, risk factors and prognostic factors. A large population-based cohort study. Sao Paulo Med. J. 2019, 137, 423-429. [CrossRef]

8. Vasquez, L.; Silva, J.; Chavez, S.; Zapata, A.; Diaz, R.; Tarrillo, F.; Maza, I.; Sialer, L.; García, J. Prognostic Impact of Diagnostic and Treatment Delays in Children with Osteosarcoma. Pediatric Blood Cancer 2020, 67, e28180. [CrossRef]

9. Yoshida, S.; Celaire, J.; Pace, C.; Taylor, C.; Kaneuchi, Y.; Evans, S.; Abudu, A. Delay in Diagnosis of Primary Osteosarcoma of Bone in Children: Have We Improved in the Last 15 Years and What Is the Impact of Delay on Diagnosis? J. Bone Oncol. 2021, 28, 100359. [CrossRef]

10. Heaton, T.E.; Hammond, W.J.; Farber, B.A.; Pallos, V.; Meyers, P.A.; Chou, A.J.; Price, A.P.; LaQuaglia, M.P. A 20-Year Retrospective Analysis of CT-Based Pre-Operative Identification of Pulmonary Metastases in Patients with Osteosarcoma: A Single-Center Review. J. Pediatr. Surg. 2017, 52, 115-119. [CrossRef]

11. Price, C.H.G.; Jeffree, G.M. Metastatic Spread of Osteosarcoma. Br. J. Cancer 1973, 28, 515-524. [CrossRef]

12. Xie, L.; Huang, W.; Wang, H.; Zheng, C.; Jiang, J. Risk Factors for Lung Metastasis at Presentation with Malignant Primary Osseous Neoplasms: A Population-Based Study. J. Orthopaed. Surg. Res. 2020, 15, 32. [CrossRef]

13. Jeffree, G.M.; Price, C.H.G.; Sissons, H.A. The Metastatic Patterns of Osteosarcoma. Br. J. Cancer 1975, 32, 87-107. [CrossRef] [PubMed]

14. Giuliano, A.E.; Feig, S.; Eilber, F.R. Changing Metastatic Patterns of Osteosarcoma. Cancer 1984, 54, 2160-2164. [CrossRef]

15. Le Aung, L.; Gorlick, R.; Healey, J.H.; Shi, W.; Thaler, H.T.; Shorter, N.A.; Huvos, A.G.; Meyers, P.A. Metachronous Skeletal Osteosarcoma in Patients Treated with Adjuvant and Neoadjuvant Chemotherapy for Nonmetastatic Osteosarcoma. J. Clin. Oncol. 2003, 21, 342-348. [CrossRef] [PubMed]

16. Enneking, W.F.; Kagan, A. The Implications of "Skip" Metastases in Osteosarcoma. Clin. Orthopaed. Relat. Res. 1975, 111, 33-41. [CrossRef] [PubMed]

17. Wuisman, P.; Enneking, W.F. Prognosis for Patients Who Have Osteosarcoma with Skip Metastasis. J. Bone Joint Surg. 1990, 72, 60-68. [CrossRef]

18. Kager, L.; Zoubek, A.; Kastner, U.; Kempf-Bielack, B.; Potratz, J.; Kotz, R.; Exner, G.U.; Franzius, C.; Lang, S.; Maas, R.; et al. Skip Metastases in Osteosarcoma: Experience of the Cooperative Osteosarcoma Study Group. J. Clin. Oncol. 2006, 24, 1535-1541. [CrossRef]

19. Li, N.; Wei, X.; Zhang, Z.; Zhang, Y. Use Of Microwave Thermal Ablation In Management Of Skip Metastases In Extremity Osteosarcomas. Cancer Manag. Res. 2019, 11, 9843-9848. [CrossRef]

20. Barnett, J.R.; Gikas, P.; Gerrand, C.; Briggs, T.W.; Saifuddin, A. The Sensitivity, Specificity, and Diagnostic Accuracy of Whole-Bone MRI for Identifying Skip Metastases in Appendicular Osteosarcoma and Ewing Sarcoma. Skelet. Radiol. 2020, 49, 913-919. [CrossRef]

21. Yang, P.; Gilg, M.; Evans, S.; Totti, F.; Stevenson, J.; Jeys, L.; Parry, M. Survival of Osteosarcoma Patients Following Diagnosis of Synchronous Skip Metastases. J. Orthopaed. 2019, 18, 121-125. [CrossRef] [PubMed] 
22. Saifuddin, A.; Michelagnoli, M.; Pressney, I. Skip Metastases in High-Grade Intramedullary Appendicular Osteosarcoma: An Indicator of More Aggressive Disease? Skelet. Radiol. 2021, 50, 2415-2422. [CrossRef] [PubMed]

23. Corradi, D.; Wenger, D.E.; Bertoni, F.; Bacchini, P.; Bosio, S.; Goldoni, M.; Unni, K.K.; Sim, F.H.; Inwards, C.Y. Multicentric Osteosarcoma: Clinicopathologic and Radiographic Study of 56 Cases. Am. J. Clin. Pathol. 2011, 136, 799-807. [CrossRef]

24. Gherlinzoni, F.; Antoci, B.; Canale, V. Case Report 250. Multicentric Osteosarcomata (Osteosarcomatosis). Skelet. Radiol. 1983, 10, 281-285. [CrossRef]

25. Longhi, A.; Fabbri, N.; Donati, D.; Capanna, R.; Briccoli, A.; Biagini, R.; Bernini, G.; Ferrari, S.; Versari, M.; Bacci, G. Neoadjuvant Chemotherapy for Patients with Synchronous Multifocal Osteosarcoma: Results in Eleven Cases. J. Chemother. 2001, 13, 324-330. [CrossRef]

26. Gok Durnali, A.; Paksoy Turkoz, F.; Ardic Yukruk, F.; Tokluoglu, S.; Yazici, O.K.; Demirci, A.; Bal, O.; Gundogdu Buyukbas, S.; Esbah, O.; Oksuzoglu, B.; et al. Outcomes of Adolescent and Adult Patients with Lung Metastatic Osteosarcoma and Comparison of Synchronous and Metachronous Lung Metastatic Groups. PLoS ONE 2016, 11, e0152621. [CrossRef] [PubMed]

27. Wasilewski-Masker, K.; Liu, Q.; Yasui, Y.; Leisenring, W.; Meacham, L.R.; Hammond, S.; Meadows, A.T.; Robison, L.L.; Mertens, A.C. Late Recurrence in Pediatric Cancer: A Report from the Childhood Cancer Survivor Study. J. Natl. Cancer Instit. 2009, 101, 1709-1720. [CrossRef]

28. Kaneuchi, Y.; Hakozaki, M.; Yamada, H.; Hasegawa, O.; Yamada, S.; Oka, Y.; Watanabe, K.; Konno, S. Very Late Relapse of High-Grade Osteosarcoma: A Case Report and Review of the Literature. Medicine 2020, 99, e21206. [CrossRef]

29. Strauss, S.J.; McTiernan, A.; Whelan, J.S. Late Relapse of Osteosarcoma: Implications for Follow-up and Screening. Pediatr. Blood Cancer 2004, 43, 692-697. [CrossRef]

30. Bacci, G.; Ruggieri, P.; Picci, P.; Briccoli, A.; Ferraro, A.; Ferrari, S.; Tienghi, A.; Iantorno, D.; Campanacci, M. Changing Pattern of Relapse in Osteosarcoma of the Extremities Treated with Adjuvant and Neoadjuvant Chemotherapy. J. Chemother. 1995, 7 , 230-239. [CrossRef]

31. Kempf-Bielack, B.; Bielack, S.S.; Jürgens, H.; Branscheid, D.; Berdel, W.E.; Exner, G.U.; Göbel, U.; Helmke, K.; Jundt, G.; Kabisch, H.; et al. Osteosarcoma Relapse after Combined Modality Therapy: An Analysis of Unselected Patients in the Cooperative Osteosarcoma Study Group (COSS). J. Clin. Oncol. 2005, 23, 559-568. [CrossRef]

32. Bielack, S.S.; Kempf-Bielack, B.; Branscheid, D.; Carrle, D.; Friedel, G.; Helmke, K.; Kevric, M.; Jundt, G.; Kühne, T.; Maas, R.; et al. Second and Subsequent Recurrences of Osteosarcoma: Presentation, Treatment, and Outcomes of 249 Consecutive Cooperative Osteosarcoma Study Group Patients. J. Clin. Oncol. 2009, 27, 557-565. [CrossRef]

33. Thebault, E.; Piperno-Neumann, S.; Tran, D.; Pacquement, H.; Marec-Berard, P.; Lervat, C.; Castex, M.P.; Cleirec, M.; Bompas, E.; Vannier, J.P.; et al. Successive Osteosarcoma Relapses after the First Line O2006/Sarcome-09 Trial: What Can We Learn for Further Phase-II Trials? Cancers 2021, 13, 1683. [CrossRef]

34. Chi, S.N.; Conklin, L.S.; Qin, J.; Meyers, P.A.; Huvos, A.G.; Healey, J.H.; Gorlick, R. The Patterns of Relapse in Osteosarcoma: The Memorial Sloan-Kettering Experience. Pediatr. Blood Cancer 2004, 42, 46-51. [CrossRef] [PubMed]

35. Ahmed, G.; Zamzam, M.; Kamel, A.; Ahmed, S.; Salama, A.; Zaki, I.; Kamal, N.; Elshafiey, M. Effect of Timing of Pulmonary Metastasis Occurrence on the Outcome of Metastasectomy in Osteosarcoma Patients. J. Pediatr. Surg. 2019, 54, 775-779. [CrossRef] [PubMed]

36. Bao, J.; Zeng, J.; Song, C.; Yu, H.; Shi, Q.; Mai, W.; Qu, G. A Retrospective Clinicopathological Study of Osteosarcoma Patients with Metachronous Metastatic Relapse. J. Cancer 2019, 10, 2982-2990. [CrossRef] [PubMed]

37. Slade, A.D.; Warneke, C.L.; Hughes, D.P.; Lally, P.A.; Lally, K.P.; Hayes-Jordan, A.A.; Austin, M.T. Effect of Concurrent Metastatic Disease on Survival in Children and Adolescents Undergoing Lung Resection for Metastatic Osteosarcoma. J. Pediatr. Surg. 2015, 50, 157-160. [CrossRef]

38. Li, W.; Zhang, S. Survival of Patients with Primary Osteosarcoma and Lung Metastases. J. BUON 2018, 23, 1500-1504.

39. Brandal, P.; Bjerkehagen, B.; Bruland, Ø.S.; Skjeldal, S.; Bogsrud, T.V.; Hall, K.S. Synchronous and Metachronous Skeletal Osteosarcomas: The Norwegian Radium Hospital Experience. Acta Oncol. 2009, 48, 1165-1172. [CrossRef] [PubMed]

40. Simon, M.A.; Aschliman, M.A.; Thomas, N.; Mankin, H.J. Limb-Salvage Treatment versus Amputation for Osteosarcoma of the Distal End of the Femur. J. Bone Joint Surg. 1986, 68, 1331-1337. [CrossRef]

41. Bertrand, T.E.; Cruz, A.; Binitie, O.; Cheong, D.; Letson, G.D. Do Surgical Margins Affect Local Recurrence and Survival in Extremity, Nonmetastatic, High-Grade Osteosarcoma? Clin. Orthopaed. Relat. Res. 2016, 474, 677-683. [CrossRef] [PubMed]

42. Casali, P.G.; Bielack, S.; Abecassis, N.; Aro, H.T.; Bauer, S.; Biagini, R.; Bonvalot, S.; Boukovinas, I.; Bovee, J.V.M.G.; Brennan, B.; et al. Bone Sarcomas: ESMO-PaedCan-EURACAN Clinical Practice Guidelines for Diagnosis, Treatment and Follow-Up. Ann. Oncol. 2018, 29, iv79-iv95. [CrossRef]

43. Meazza, C.; Scanagatta, P. Metastatic Osteosarcoma: A Challenging Multidisciplinary Treatment. Expert Rev. Anticancer Ther. 2016, 16, 543-556. [CrossRef]

44. Gazouli, I.; Kyriazoglou, A.; Kotsantis, I.; Anastasiou, M.; Pantazopoulos, A.; Prevezanou, M.; Chatzidakis, I.; Kavourakis, G.; Economopoulou, P.; Kontogeorgakos, V.; et al. Systematic Review of Recurrent Osteosarcoma Systemic Therapy. Cancers 2021, 13, 1757. [CrossRef] [PubMed]

45. Lavit, E.; Aldea, M.; Piperno-Neumann, S.; Firmin, N.; Italiano, A.; Isambert, N.; Kurtz, J.E.; Delcambre, C.; Lebrun, V.; SoibinetOudot, P.; et al. Treatment of 120 Adult Osteosarcoma Patients with Metachronous and Synchronous Metastases: A Retrospective Series of the French Sarcoma Group. Int. J. Cancer 2021, 150, 645-653. [CrossRef] 
46. Fagioli, F.; Aglietta, M.; Tienghi, A.; Ferrari, S.; Brach del Prever, A.; Vassallo, E.; Palmero, A.; Biasin, E.; Bacci, G.; Picci, P.; et al. High-Dose Chemotherapy in the Treatment of Relapsed Osteosarcoma: An Italian Sarcoma Group Study. J. Clin. Oncol. 2002, 20, 2150-2156. [CrossRef]

47. Tawbi, H.A.; Burgess, M.; Bolejack, V.; van Tine, B.A.; Schuetze, S.M.; Hu, J.; D'Angelo, S.; Attia, S.; Riedel, R.F.; Priebat, D.A.; et al. Pembrolizumab in Advanced Soft-Tissue Sarcoma and Bone Sarcoma (SARC028): A Multicentre, Two-Cohort, Single-Arm, Open-Label, Phase 2 Trial. Lancet Oncol. 2017, 18, 1493-1501. [CrossRef]

48. Burgess, M.; Tawbi, H. Immunotherapeutic Approaches to Sarcoma. Curr. Treat. Options Oncol. 2015, 16, 26. [CrossRef]

49. Merchant, M.S.; Bernstein, D.; Amoako, M.; Baird, K.; Fleisher, T.A.; Morre, M.; Steinberg, S.M.; Sabatino, M.; Stroncek, D.F.; Venkatasan, A.M.; et al. Adjuvant Immunotherapy to Improve Outcome in High-Risk Pediatric Sarcomas. Clin. Cancer Res. 2016, 22, 3182-3191. [CrossRef] [PubMed]

50. Ahmed, N.; Brawley, V.S.; Hegde, M.; Robertson, C.; Ghazi, A.; Gerken, C.; Liu, E.; Dakhova, O.; Ashoori, A.; Corder, A.; et al. Human Epidermal Growth Factor Receptor 2 (HER2)—Specific Chimeric Antigen Receptor-Modified T Cells for the Immunotherapy of HER2-Positive Sarcoma. J. Clin. Oncol. 2015, 33, 1688-1696. [CrossRef]

51. Krishnamoorthy, N.; Desai, S.S.; Rekhi, B.; Jambhekar, N.A. A Clinico-Morphological Study of 95 Cases of Sarcomas with Metastases to the Lungs. Indian J. Cancer 2011, 48, 335-338. [CrossRef] [PubMed]

52. Wang, D.; Niu, X.; Wang, Z.; Song, C.L.; Huang, Z.; Chen, K.N.; Duan, J.; Bai, H.; Xu, J.; Zhao, J.; et al. Multiregion Sequencing Reveals the Genetic Heterogeneity and Evolutionary History of Osteosarcoma and Matched Pulmonary Metastases. Cancer Res. 2019, 79, 7-20. [CrossRef] [PubMed]

53. Xu, H.; Zhu, X.; Bao, H.; Shek, T.W.; Huang, Z.; Wang, Y.; Wu, X.; Wu, Y.; Chang, Z.; Wu, S.; et al. Genetic and Clonal Dissection of Osteosarcoma Progression and Lung Metastasis. Int. J. Cancer 2018, 143, 1134-1142. [CrossRef]

54. Moriarity, B.S.; Otto, G.M.; Rahrmann, E.P.; Rathe, S.K.; Wolf, N.K.; Weg, M.T.; Manlove, L.A.; Larue, R.S.; Temiz, N.A.; Molyneux, S.D.; et al. A Sleeping Beauty Forward Genetic Screen Identifies New Genes and Pathways Driving Osteosarcoma Development and Metastasis. Nat. Genet. 2015, 47, 615-624. [CrossRef] [PubMed]

55. Stoecklein, N.H.; Klein, C.A. Genetic Disparity between Primary Tumours, Disseminated Tumour Cells, and Manifest Metastasis Int. J. Cancer 2010, 126, 589-598. [CrossRef] [PubMed]

56. Klein, C.A. Parallel Progression of Primary Tumours and Metastases. Nat. Rev. Cancer 2009, 9, 302-312. [CrossRef]

57. Li, M.; Lu, Y.; Long, Z.; Li, M.; Kong, J.; Chen, G.; Wang, Z. Prognostic and Clinicopathological Significance of Circulating Tumor Cells in Osteosarcoma. J. Bone Oncol. 2019, 16, 100236. [CrossRef]

58. Wu, Z.J.; Tan, J.C.; Qin, X.; Liu, B.; Yuan, Z.C. Significance of Circulating Tumor Cells in Osteosarcoma Patients Treated by Neoadjuvant Chemotherapy and Surgery. Cancer Manag. Res. 2018, 10, 3333-3339. [CrossRef] [PubMed]

59. Adamopoulos, C.; Gargalionis, A.N.; Basdra, E.K.; Papavassiliou, A.G. Deciphering Signaling Networks in Osteosarcoma Pathobiology. Exp. Biol. Med. 2016, 241, 1296-1305. [CrossRef]

60. Li, Z.; Li, X.; Xu, D.; Chen, X.; Li, S.; Zhang, L.; Chan, M.T.V.; Wu, W.K.K. An Update on the Roles of Circular RNAs in Osteosarcoma. Cell Proliferat. 2021, 54, e12936. [CrossRef]

61. Zhang, Y.; Li, J.; Wang, Y.; Jing, J.; Li, J. The Roles of Circular RNAs in Osteosarcoma. Med. Sci. Monit. 2019, 25, 6378-6382. [CrossRef] [PubMed]

62. Kushlinskii, N.E.; Fridman, M.V.; Braga, E.A. Long Non-Coding RNAs as Competitive Endogenous RNAs in Osteosarcoma. Mol Biol. 2020, 54, 776-801. [CrossRef]

63. Botti, G.; Giordano, A.; Feroce, F.; Chiara, A.R. de Cantile, M. Noncoding RNAs as Circulating Biomarkers in Osteosarcoma Patients. J. Cell. Physiol. 2019, 234, 19249-19255. [CrossRef]

64. Llobat, L.; Gourbault, O. Role of Micrornas in Human Osteosarcoma: Future Perspectives. Biomedicines 2021, 9, 463. [CrossRef] [PubMed]

65. Zhang, J.; Yan, Y.G.; Wang, C.; Zhang, S.J.; Yu, X.H.; Wang, W.J. MicroRNAs in Osteosarcoma. Clin. Chim. Acta 2015, 444, 9-17. [CrossRef]

66. Jamali, Z.; Taheri-Anganeh, M.; Shabaninejad, Z.; Keshavarzi, A.; Taghizadeh, H.; Razavi, Z.S.; Mottaghi, R.; Abolhassan, M.; Movahedpour, A.; Mirzaei, H. Autophagy Regulation by MicroRNAs: Novel Insights into Osteosarcoma Therapy. IUBMB Life 2020, 72, 1306-1321. [CrossRef]

67. Zheng, D.; Xia, K.; Yu, L.; Gong, C.; Shi, Y.; Li, W.; Qiu, Y.; Yang, J.; Guo, W. A Novel Six Metastasis-Related Prognostic Gene Signature for Patients With Osteosarcoma. Front. Cell Dev. Biol. 2021, 9, 699212. [CrossRef]

68. Ying, T.; Dong, J.L.; Yuan, C.; Li, P.; Guo, Q. The LncRNAs RP1-261G23.7, RP11-69E11.4 and SATB2-AS1 Are a Novel Clinical Signature for Predicting Recurrent Osteosarcoma. Biosci. Rep. 2020, 40, BSR20191251. [CrossRef]

69. Shi, Y.; He, R.; Zhuang, Z.; Ren, J.; Wang, Z.; Liu, Y.; Wu, J.; Jiang, S.; Wang, K. A Risk Signature-Based on Metastasis-Associated Genes to Predict Survival of Patients with Osteosarcoma. J. Cell. Biochem. 2020, 121, 3479-3490. [CrossRef]

70. Qi, W.; Yan, Q.; Lv, M.; Song, D.; Wang, X.; Tian, K. Prognostic Signature of Osteosarcoma Based on 14 Autophagy-Related Genes. Pathol. Oncol. Res. 2021, 27, 1609782. [CrossRef]

71. Jiang, F.; Miao, X.-L.; Zhang, X.-T.; Yan, F.; Mao, Y.; Wu, C.-Y.; Zhou, G.-P. A Hypoxia Gene-Based Signature to Predict the Survival and Affect the Tumor Immune Microenvironment of Osteosarcoma in Children. J. Immunol. Res. 2021, 2021, 5523832. [CrossRef]

72. Yang, M.; Ma, X.; Wang, Z.; Zhang, T.; Hua, Y. Identification of a Novel Glycolysis-Related Gene Signature for Predicting the Prognosis of Osteosarcoma Patients. Aging 2021, 13, 12896-12918. [CrossRef] 
73. Xiao, K.W.; Liu, Z.B.; Zeng, Z.H.; Yan, F.F.; Xiao, L.F.; Li, J.L.; Cai, L. Construction and Validation of a Macrophage-Associated Risk Model for Predicting the Prognosis of Osteosarcoma. J. Oncol. 2021, 2021, 9967954. [CrossRef]

74. Chong, Z.X.; Yeap, S.K.; Ho, W.Y. Unraveling the Roles of MiRNAs in Regulating Epithelial-to-Mesenchymal Transition (EMT) in Osteosarcoma. Pharmacol. Res. 2021, 172, 105818. [CrossRef]

75. Ehnman, M.; Chaabane, W.; Haglund, F.; Tsagkozis, P. The Tumor Microenvironment of Pediatric Sarcoma: Mesenchymal Mechanisms Regulating Cell Migration and Metastasis. Curr. Oncol. Rep. 2019, 21, 90. [CrossRef] [PubMed]

76. Wang, J.; Zhang, H.; Sun, X.; Wang, X.; Ren, T.; Huang, Y.; Zhang, R.; Zheng, B.; Guo, W. Exosomal PD-L1 and N-Cadherin Predict Pulmonary Metastasis Progression for Osteosarcoma Patients. J. Nanobiotechnol. 2020, 18, 151. [CrossRef] [PubMed]

77. Jiang, R.; Zhang, C.; Liu, G.; Gu, R.; Wu, H. MicroRNA-126 Inhibits Proliferation, Migration, Invasion, and EMT in Osteosarcoma by Targeting ZEB1. J. Cell. Biochem. 2017, 118, 3765-3774. [CrossRef] [PubMed]

78. Yao, H.; Hou, G.; Wang, Q.Y.; Xu, W.B.; Zhao, H.Q.; Xu, Y.C. LncRNA SPRY4-IT1 Promotes Progression of Osteosarcoma by Regulating ZEB1 and ZEB2 Expression through Sponging of MiR-101 Activity. Int. J. Oncol. 2020, 56, 85-100. [CrossRef]

79. Feng, T.; Zhu, Z.; Jin, Y.; Wang, H.; Mao, X.; Liu, D.; Li, Y.; Lu, L.; Zuo, G. The MicroRNA-708-5p/ZEB1/EMT Axis Mediates the Metastatic Potential of Osteosarcoma. Oncol. Rep. 2020, 43, 491-502. [CrossRef]

80. Zhu, S.T.; Wang, X.; Wang, J.Y.; Xi, G.H.; Liu, Y. Downregulation of MiR-22 Contributes to Epithelial-Mesenchymal Transition in Osteosarcoma by Targeting Twist1. Front. Oncol. 2020, 10, 406. [CrossRef]

81. Chen, Y.; Li, J.; Xiao, J.K.; Xiao, L.; Xu, B.W.; Li, C. The LncRNA NEAT1 Promotes the Epithelial-Mesenchymal Transition and Metastasis of Osteosarcoma Cells by Sponging MiR-483 to Upregulate STAT3 Expression. Cancer Cell Int. 2021, 21, 90. [CrossRef]

82. Zhang, S.; Chen, H.; Liu, W.; Fang, L.; Qian, Z.; Kong, R.; Zhang, Q.; Li, J.; Cao, X. MiR-766-3p Targeting BCL9L Suppressed Tumorigenesis, Epithelial-Mesenchymal Transition, and Metastasis Through the $\beta$-Catenin Signaling Pathway in Osteosarcoma Cells. Front. Cell Dev. Biol. 2020, 8, 1086. [CrossRef] [PubMed]

83. Wang, H.; Zhang, P. LncRNA-CASC15 Promotes Osteosarcoma Proliferation and Metastasis by Regulating EpithelialMesenchymal Transition via the Wnt/ $\beta$-Catenin Signaling Pathway. Oncol. Rep. 2021, 45, 76. [CrossRef]

84. Kovar, H.; Bierbaumer, L.; Radic-Sarikas, B. The YAP/TAZ Pathway in Osteogenesis and Bone Sarcoma Pathogenesis. Cells 2020, 9, 972. [CrossRef] [PubMed]

85. Calvo, F.; Ege, N.; Grande-Garcia, A.; Hooper, S.; Jenkins, R.P.; Chaudhry, S.I.; Harrington, K.; Williamson, P.; Moeendarbary, E.; Charras, G.; et al. Mechanotransduction and YAP-Dependent Matrix Remodelling Is Required for the Generation and Maintenance of Cancer-Associated Fibroblasts. Nat. Cell Biol. 2013, 15, 637-646. [CrossRef]

86. Pavel, M.; Renna, M.; Park, S.J.; Menzies, F.M.; Ricketts, T.; Füllgrabe, J.; Ashkenazi, A.; Frake, R.A.; Lombarte, A.C.; Bento, C.F.; et al. Contact Inhibition Controls Cell Survival and Proliferation via YAP/TAZ-Autophagy Axis. Nat. Commun. 2018, 9, 2961. [CrossRef]

87. Xiang, L.; Gilkes, D.M.; Hu, H.; Luo, W.; Bullen, J.W.; Liang, H.; Semenza, G.L. HIF-1 $\alpha$ and TAZ Serve as Reciprocal Co-Activators in Human Breast Cancer Cells. Oncotarget 2015, 6, 11768-11778. [CrossRef] [PubMed]

88. Zhao, B.; Lv, Y. Suspension State and Shear Stress Enhance Breast Tumor Cells EMT through YAP by MicroRNA-29b. Cell Biol. Toxicol. 2021. [CrossRef]

89. Di Benedetto, G.; Parisi, S.; Russo, T.; Passaro, F. YAP and TAZ Mediators at the Crossroad between Metabolic and Cellular Reprogramming. Metabolites 2021, 11, 154. [CrossRef]

90. Varelas, X. The Hippo Pathway Effectors TAZ and YAP in Development, Homeostasis and Disease. Development 2014, 141, 1614-1626. [CrossRef]

91. Jansen, S.; Gosens, R.; Wieland, T.; Schmidt, M. Paving the Rho in Cancer Metastasis: Rho GTPases and Beyond. Pharmacol. Ther 2018, 183, 1-21. [CrossRef] [PubMed]

92. Li, H.L.; Li, Q.Y.; Jin, M.J.; Lu, C.F.; Mu, Z.Y.; Xu, W.Y.; Song, J.; Zhang, Y.; Zhang, S.Y. A Review: Hippo Signaling Pathway Promotes Tumor Invasion and Metastasis by Regulating Target Gene Expression. J. Cancer Res. Clin. Oncol. 2021, 147, 1569-1585. [CrossRef] [PubMed]

93. Tang, Y.; Weiss, S.J. Snail/Slug-YAP/TAZ Complexes Cooperatively Regulate Mesenchymal Stem Cell Function and Bone Formation. Cell Cycle 2017, 16, 399-405. [CrossRef] [PubMed]

94. Sun, Z.; Schwenzer, A.; Rupp, T.; Murdamoothoo, D.; Vegliante, R.; Lefebvre, O.; Klein, A.; Hussenet, T.; Orend, G. Tenascin-C Promotes Tumor Cell Migration and Metastasis through Integrin A9b1-Mediated YAP Inhibition. Cancer Res. 2018, 78, 950-961. [CrossRef] [PubMed]

95. Yudoh, K.; Matsui, H.; Kanamori, M.; Ohmori, K.; Yasuda, T.; Tsuji, H. Characteristics of High and Low Laminin-Adherent Dunn Osteosarcoma Cells Selected by Adhesiveness to Laminin. Tumor Biol. 1996, 17, 332-340. [CrossRef]

96. Gvozdenovic, A.; Boro, A.; Meier, D.; Bode-Lesniewska, B.; Born, W.; Muff, R.; Fuchs, B. Targeting Av $\beta 3$ and Av $\beta 5$ Integrins Inhibits Pulmonary Metastasis in an Intratibial Xenograft Osteosarcoma Mouse Model. Oncotarget 2016, 7, 55141-55154. [CrossRef]

97. Zandueta, C.; Ormazábal, C.; Perurena, N.; Martínez-Canarias, S.; Zalacaín, M.; Julián, M.S.; Grigoriadis, A.E.; Valencia, K.; Campos-Laborie, F.J.; De las Rivas, J.; et al. Matrix-Gla Protein Promotes Osteosarcoma Lung Metastasis and Associates with Poor Prognosis. J. Pathol. 2016, 239, 438-449. [CrossRef]

98. Kitamura, T.; Qian, B.Z.; Pollard, J.W. Immune Cell Promotion of Metastasis. Nat. Rev. Immunol. 2015, 15, 73-86. [CrossRef] 
99. Han, Y.; Guo, W.; Ren, T.; Huang, Y.; Wang, S.; Liu, K.; Zheng, B.; Yang, K.; Zhang, H.; Liang, X. Tumor-Associated Macrophages Promote Lung Metastasis and Induce Epithelial-Mesenchymal Transition in Osteosarcoma by Activating the COX-2/STAT3 Axis. Cancer Lett. 2019, 440-441, 116-125. [CrossRef]

100. Maloney, C.; Kallis, M.P.; Edelman, M.; Tzanavaris, C.; Lesser, M.; Soffer, S.Z.; Symons, M.; Steinberg, B.M. Gefitinib Inhibits Invasion and Metastasis of Osteosarcoma via Inhibition of Macrophage Receptor Interacting Serine-Threonine Kinase 2. Mol. Cancer Ther. 2020, 19, 1340-1350. [CrossRef]

101. Nardin, A.; Lefebvre, M.; Labroquere, K.; Faure, O.; Abastado, J. Liposomal Muramyl Tripeptide Phosphatidylethanolamine: Targeting and Activating Macrophages for Adjuvant Treatment of Osteosarcoma. Curr. Cancer Drug Targets 2006, 6, 123-133. [CrossRef]

102. Meyers, P.A. Muramyl Tripeptide-Phosphatidyl Ethanolamine Encapsulated in Liposomes (L-MTP-PE) in the Treatment of Osteosarcoma. Adv. Exp. Med. Biol. 2020, 1257, 133-139. [PubMed]

103. Gomez-Brouchet, A.; Illac, C.; Gilhodes, J.; Bouvier, C.; Aubert, S.; Guinebretiere, J.M.; Marie, B.; Larousserie, F.; Entz-Werlé, N.; de Pinieux, G.; et al. CD163-Positive Tumor-Associated Macrophages and CD8-Positive Cytotoxic Lymphocytes Are Powerful Diagnostic Markers for the Therapeutic Stratification of Osteosarcoma Patients: An Immunohistochemical Analysis of the Biopsies Fromthe French OS2006 Phase 3 t. OncoImmunology 2017, 6, e1331193. [CrossRef] [PubMed]

104. Buddingh, E.P.; Kuijjer, M.L.; Duim, R.A.J.; Bürger, H.; Agelopoulos, K.; Myklebost, O.; Serra, M.; Mertens, F.; Hogendoorn, P.C.W.; Lankester, A.C.; et al. Tumor-Infiltrating Macrophages Are Associated with Metastasis Suppression in High-Grade Osteosarcoma: A Rationale for Treatment with Macrophage Activating Agents. Clin. Cancer Res. 2011, 17, 2110-2119. [CrossRef] [PubMed]

105. Dumars, C.; Ngyuen, J.M.; Gaultier, A.; Lanel, R.; Corradini, N.; Gouin, F.; Heymann, D.; Heymann, M.F. Dysregulation of Macrophage Polarization Is Associated with the Metastatic Process in Osteosarcoma. Oncotarget 2016, 7, 78343-78354. [CrossRef] [PubMed]

106. Zhou, Y.; Yang, D.; Yang, Q.; Lv, X.; Huang, W.; Zhou, Z.; Wang, Y.; Zhang, Z.; Yuan, T.; Ding, X.; et al. Single-Cell RNA Landscape of Intratumoral Heterogeneity and Immunosuppressive Microenvironment in Advanced Osteosarcoma. Nat. Commun. 2020, 11, 6322. [CrossRef]

107. Niu, J.; Yan, T.; Guo, W.; Wang, W.; Zhao, Z.; Ren, T.; Huang, Y.; Zhang, H.; Yu, Y.; Liang, X. Identification of Potential Therapeutic Targets and Immune Cell Infiltration Characteristics in Osteosarcoma Using Bioinformatics Strategy. Front. Oncol. 2020, 10, 1628. [CrossRef]

108. Wong, C.W.; Lee, A.; Shientag, L.; Yu, J.; Dong, Y.; Kao, G.; Al-Mehdi, A.B.; Bernhard, E.J.; Muschel, R.J. Apoptosis: An Early Event in Metastatic Inefficiency. Cancer Res. 2001, 61, 333-338.

109. Bonner, S.E.; Willms, E. Intercellular Communication through Extracellular Vesicles in Cancer and Evolutionary Biology. Prog. Biophys. Mol. Biol. 2021, 165, 80-87. [CrossRef]

110. Macklin, R.; Wang, H.; Loo, D.; Martin, S.; Cumming, A.; Cai, N.; Lane, R.; Ponce, N.S.; Topkas, E.; Inder, K.; et al. Extracellular Vesicles Secreted by Highly Metastatic Clonal Variants of Osteosarcoma Preferentially Localize to the Lungs and Induce Metastatic Behaviour in Poorly Metastatic Clones. Oncotarget 2016, 7, 43570-43587. [CrossRef]

111. Zhong, L.; Liao, D.; Li, J.; Liu, W.; Wang, J.; Zeng, C.; Wang, X.; Cao, Z.; Zhang, R.; Li, M.; et al. Rab22a-NeoF1 Fusion Protein Promotes Osteosarcoma Lung Metastasis through Its Secretion into Exosomes. Signal Transduct. Target. Ther. 2021, 6, 59. [CrossRef] [PubMed]

112. Mazumdar, A.; Urdinez, J.; Boro, A.; Migliavacca, J.; Arlt, M.J.E.; Muff, R.; Fuchs, B.; Snedeker, J.G.; Gvozdenovic, A. OsteosarcomaDerived Extracellular Vesicles Induce Lung Fibroblast Reprogramming. Int. J. Mol. Sci. 2020, 21, 5451. [CrossRef] [PubMed]

113. Mazumdar, A.; Urdinez, J.; Boro, A.; Arlt, M.J.E.; Egli, F.E.; Niederöst, B.; Jaeger, P.K.; Moschini, G.; Muff, R.; Fuchs, B.; et al. Exploring the Role of Osteosarcoma-Derived Extracellular Vesicles in Pre-Metastatic Niche Formation and Metastasis in the 143-b Xenograft Mouse Osteosarcoma Model. Cancers 2020, 12, 3457. [CrossRef] [PubMed]

114. Nineteenth Century Foundations of Cancer Research. Origins of Experimental Research-PubMed. Available online: https://pubmedncbi-nlm-nih-gov.proxy.insermbiblio.inist.fr/14106160/ (accessed on 23 September 2021).

115. The Distribution of Secondary Growths in Cancer of the Breast. 1889-PubMed. Available online: https://pubmed-ncbi-nlmnih-gov.proxy.insermbiblio.inist.fr/2673568/ (accessed on 23 September 2021).

116. Gambera, S.; Abarrategi, A.; González-Camacho, F.; Morales-Molina, Á.; Roma, J.; Alfranca, A.; García-Castro, J. Clonal Dynamics in Osteosarcoma Defined by RGB Marking. Nat. Commun. 2018, 9, 3994. [CrossRef] [PubMed]

117. Liu, Y.; Feng, W.; Dai, Y.; Bao, M.; Yuan, Z.; He, M.; Qin, Z.; Liao, S.; He, J.; Huang, Q.; et al. Single-Cell Transcriptomics Reveals the Complexity of the Tumor Microenvironment of Treatment-Naive Osteosarcoma. Front. Oncol. 2021, 11, 709210. [CrossRef]

118. Couturier, C.P.; Ayyadhury, S.; Le, P.U.; Nadaf, J.; Monlong, J.; Riva, G.; Allache, R.; Baig, S.; Yan, X.; Bourgey, M.; et al. Single-Cell RNA-Seq Reveals That Glioblastoma Recapitulates a Normal Neurodevelopmental Hierarchy. Nat. Commun. 2020, $11,3406$. [CrossRef] [PubMed]

119. Pan, X.W.; Zhang, H.; Xu, D.; Chen, J.X.; Chen, W.J.; Gan, S.S.; Qu, F.J.; Chu, C.M.; Cao, J.W.; Fan, Y.H.; et al. Identification of a Novel Cancer Stem Cell Subpopulation That Promotes Progression of Human Fatal Renal Cell Carcinoma by Single-Cell RNA-Seq Analysis. Int. J. Biol. Sci. 2020, 16, 3149-3162. [CrossRef]

120. Tian, J.; Li, X.; Si, M.; Liu, T.; Li, J. CD271+ Osteosarcoma Cells Display Stem-Like Properties. PLoS ONE 2014, 9, e98549. [CrossRef]

121. Gibbs, C.P.; Kukekov, V.G.; Reith, J.D.; Tchigrinova, O.; Suslov, O.N.; Scott, E.W.; Ghivizzani, S.C.; Ignatova, T.N.; Steindler, D.A. Stem-like Cells in Bone Sarcomas: Implications for Tumorigenesis. Neoplasia 2005, 7, 967-976. [CrossRef] 
122. Andrique, C.; Morardet, L.; Linares, L.K.; Cissé, M.Y.; Merle, C.; Chibon, F.; Provot, S.; Haÿ, E.; Ea, H.-K.; Cohen-Solal, M.; et al. Calpain-6 Controls the Fate of Sarcoma Stem Cells by Promoting Autophagy and Preventing Senescence. JCI Insight 2018, 3, 121225. [CrossRef]

123. He, H.; Ni, J.; Huang, J. Molecular Mechanisms of Chemoresistance in Osteosarcoma (Review). Oncol. Lett. 2014, 7, 1352-1362. [CrossRef] [PubMed]

124. Chandimali, N.; Koh, H.; Kim, J.; Lee, J.; Park, Y.H.; Sun, H.N.; Kwon, T. Brm270 Targets Cancer Stem Cells and Augments Chemo-Sensitivity in Cancer (Review). Oncol. Lett. 2020, 20, 103. [CrossRef]

125. Marion, A.; Dieudonné, F.-X.; Patiño-Garcia, A.; Lecanda, F.; Marie, P.J.; Modrowski, D. Calpain-6 Is an Endothelin-1 Signaling Dependent Protective Factor in Chemoresistant Osteosarcoma. Int. J. Cancer 2012, 130, 2514-2525. [CrossRef] [PubMed]

126. Li, Y.; Xian, M.; Yang, B.; Ying, M.; He, Q. Inhibition of KLF4 by Statins Reverses Adriamycin-Induced Metastasis and Cancer Stemness in Osteosarcoma Cells. Stem Cell Rep. 2017, 8, 1617-1629. [CrossRef]

127. Lawson, D.A.; Bhakta, N.R.; Kessenbrock, K.; Prummel, K.D.; Yu, Y.; Takai, K.; Zhou, A.; Eyob, H.; Balakrishnan, S.; Wang, C.-Y.; et al. Single-Cell Analysis Reveals a Stem-Cell Program in Human Metastatic Breast Cancer Cells. Nature 2015, 526, 131-135. [CrossRef] [PubMed]

128. Radisky, D.C.; LaBarge, M.A. Epithelial-Mesenchymal Transition and the Stem Cell Phenotype. Cell Stem Cell 2008, 2, 511-512. [CrossRef]

129. Mani, S.A.; Guo, W.; Liao, M.J.; Eaton, E.N.; Ayyanan, A.; Zhou, A.Y.; Brooks, M.; Reinhard, F.; Zhang, C.C.; Shipitsin, M.; et al. The Epithelial-Mesenchymal Transition Generates Cells with Properties of Stem Cells. Cell 2008, 133, 704-715. [CrossRef]

130. Pastushenko, I.; Mauri, F.; Song, Y.; de Cock, F.; Meeusen, B.; Swedlund, B.; Impens, F.; van Haver, D.; Opitz, M.; Thery, M.; et al Fat1 Deletion Promotes Hybrid EMT State, Tumour Stemness and Metastasis. Nature 2021, 589, 448-455. [CrossRef]

131. Castaño, Z.; San Juan, B.P.; Spiegel, A.; Pant, A.; DeCristo, M.J.; Laszewski, T.; Ubellacker, J.M.; Janssen, S.R.; Dongre, A.; Reinhardt, F; et al. IL-1 $\beta$ Inflammatory Response Driven by Primary Breast Cancer Prevents Metastasis-Initiating Cell Colonization. Nat. Cell Biol. 2018, 20, 1084-1097. [CrossRef]

132. Yao, J.; Lin, J.; He, L.; Huang, J.; Liu, Q. TNF- $\alpha$ /MiR-155 Axis Induces the Transformation of Osteosarcoma Cancer Stem Cells Independent of TP53INP1. Gene 2020, 726, 144224. [CrossRef]

133. Xu, M.; Jin, H.; Xu, C.X.; Sun, B.; Song, Z.G.; Bi, W.Z.; Wang, Y. MiR-382 Inhibits Osteosarcoma Metastasis and Relapse by Targeting Y Box-Binding Protein 1. Mol. Ther. 2015, 23, 89-98. [CrossRef] [PubMed]

134. Rodriguez-Torres, M.; Allan, A.L. Aldehyde Dehydrogenase as a Marker and Functional Mediator of Metastasis in Solid Tumors Clin. Exp. Metastasis 2016, 33, 97-113. [CrossRef]

135. Fuja, D.G.; Rainusso, N.C.; Shuck, R.L.; Kurenbekova, L.; Donehower, L.A.; Yustein, J.T. Transglutaminase-2 Promotes Metastatic and Stem-like Phenotypes in Osteosarcoma. Am. J. Cancer Res. 2018, 8, 1752-1763.

136. Zhang, W.; Zhao, J.M.; Lin, J.; Hu, C.Z.; Zhang, W.B.; Yang, W.L.; Zhang, J.; Zhang, J.W.; Zhu, J. Adaptive Fibrogenic Reprogramming of Osteosarcoma Stem Cells Promotes Metastatic Growth. Cell Rep. 2018, 24, 1266-1277. [CrossRef] [PubMed]

137. Silver, D.J.; Sinyuk, M.; Vogelbaum, M.A.; Ahluwalia, M.S.; Lathia, J.D. The Intersection of Cancer, Cancer Stem Cells, and the Immune System: Therapeutic Opportunities. Neuro-Oncol. 2016, 18, 153-159. [CrossRef]

138. Pardoll, D. Cancer and Immune System: Basic Concepts and Targets for Intervention. Semin. Oncol. 2015, 42, 523-538. [CrossRef]

139. Concha-Benavente, F.; Srivastava, R.; Ferrone, S.; Ferris, R.L. Immunological and Clinical Significance of HLA Class I Antigen Processing Machinery Component Defects in Malignant Cells. Oral Oncol. 2016, 58, 52-58. [CrossRef] [PubMed]

140. Wu, Y.; Chen, M.; Wu, P.; Chen, C.; Xu, Z.P.; Gu, W. Increased PD-L1 Expression in Breast and Colon Cancer Stem Cells. Clin. Exp. Pharmacol. Physiol. 2017, 44, 602-604. [CrossRef] [PubMed]

141. Wei, J.; Barr, J.; Kong, L.Y.; Wang, Y.; Wu, A.; Sharma, A.K.; Gumin, J.; Henry, V.; Colman, H.; Priebe, W.; et al. Glioblastoma CancerInitiating Cells Inhibit T-Cell Proliferation and Effector Responses by the Signal Transducers and Activators of Transcription 3 Pathway. Mol. Cancer Ther. 2010, 9, 67-78. [CrossRef]

142. Jachetti, E.; Caputo, S.; Mazzoleni, S.; Brambillasca, C.S.; Parigi, S.M.; Grioni, M.; Piras, I.S.; Restuccia, U.; Calcinotto, A.; Freschi, M.; et al. Tenascin-C Protects Cancer Stem-like Cells from Immune Surveillance by Arresting T-Cell Activation. Cancer Res. 2015, 75, 2095-2108. [CrossRef]

143. Marec-Berard, P.; Dalban, C.; Gaspar, N.; Brugieres, L.; Gentet, J.C.; Lervat, C.; Corradini, N.; Castex, M.P.; Schmitt, C.; Pacquement, H.; et al. A Multicentric Randomized Phase II Clinical Trial Evaluating High-Dose Thiotepa as Adjuvant Treatment to Standard Chemotherapy in Patients with Resectable Relapsed Osteosarcoma. Eur. J. Cancer 2020, 125, 58-68. [CrossRef] [PubMed]

144. Italiano, A.; Mir, O.; Mathoulin-Pelissier, S.; Penel, N.; Piperno-Neumann, S.; Bompas, E.; Chevreau, C.; Duffaud, F.; Entz-Werlé, N.; Saada, E.; et al. Cabozantinib in Patients with Advanced Ewing Sarcoma or Osteosarcoma (CABONE): A Multicentre, Single-Arm, Phase 2 Trial. Lancet Oncol. 2020, 21, 446-455. [CrossRef]

145. Boye, K.; Longhi, A.; Guren, T.; Lorenz, S.; Næss, S.; Pierini, M.; Taksdal, I.; Lobmaier, I.; Cesari, M.; Paioli, A.; et al. Pembrolizumab in Advanced Osteosarcoma: Results of a Single-Arm, Open-Label, Phase 2 Trial. Cancer Immunol. Immunother. 2021, 70, 2617-2624. [CrossRef] [PubMed]

146. Qayed, M.; Cash, T.; Tighiouart, M.; MacDonald, T.J.; Goldsmith, K.C.; Tanos, R.; Kean, L.; Watkins, B.; Suessmuth, Y.; Wetmore, C.; et al. A Phase I Study of Sirolimus in Combination with Metronomic Therapy (CHOAnome) in Children with Recurrent or Refractory Solid and Brain Tumors. Pediatr. Blood Cancer 2020, 67, 28134. [CrossRef] [PubMed] 